\title{
Digestibility and feeding value of some tropical grasses and kudzu
}

\author{
N. D. DIJKSTRA and J. G. P. DIRVEN \\ Institute for Farm-animal Feeding Research at Hoorn, Netherlands
}

\begin{abstract}
Summary
A research was made into the digestibility and feeding value of 5 lots of different grasses and 2 lots of $k u d z u$ grown in Surinam. In view of the transport to Holland all lots were artificially dried. Each experiment was made by use of 3 wethers. The results of the digestion trials are mentioned in table 1 and 2 and the calculated feeding value figures in table 3.

In the same way as in Dutch roughages we examined how the feeding value of tropical grass could be correlated with its chemical composition. It proves that there was a very good correlation between crude protein and digestible crude protein (fig. 1) and a fair correlation between crude fibre and starch equivalent (fig. 2). Both relations are recorded in regression formulae.
\end{abstract}

\section{Introduction}

In experiments on the Government Livestock Farm at Paramaribo, Surinam, the milk production of cattle on improved and heavily fertilized pastures varied without use of concentrates from $6-8 \mathrm{~kg}$ per day. With the application of a semi-rotational grazing system the animals were brought into a fresh pasture every 16 days. Consequently, the consumed grass was moderately young with a dig. crude protein content of $8,1-$ 15,7 per cent; high figures considering the circumstances prevailing in Surinam.

Notwithstanding this the live weight and also the milk production showed a tendency to decrease. This finding suggested that there was probably something wrong with the energy intake and consequently with the starch equivalent of the grass. This was obvious, because the crude-fibre content of even young grass of pastures in Surinam is very high.

Consequently, the grassland agronomist of the Livestock Farm wanted to obtain more data about the feeding value of the Surinam pastures and, therefore, the Institute for Farm-animal Feeding Research at Hoorn was asked to determine the digestibility of a number of grasses and two samples of kudzu (Pueraria phaseoloides).

When fodder grasses, i.e. elephant, guatemala and para grass are harvested too frequently, undoubtedly the yields of the grasses will decrease quickly. By mowing kudzu caution must be exercised to avoid injury to the stand.

Because the number of samples had to be limited, we have adapted in this research the circumstances of the practice. Consequently, the grasses and $k u d z u$ are harvested in a state which also can be realized under normal conditions prevailing in Surinam.

In view of the transport to Hoorn the material had to be dried artificially. Directly after cutting the crop was taken to the Agricultural Technical Division of the Experiment Station at Paramaribo, where it was dried in a tunnel-drier at a temperature

Received for publication 30th April, 1962.

Neth. J. agric. Sci., Vol. 10 (1962) No. 4 (November) 
of about $75-80^{\circ} \mathrm{C}$. After drying the product was ground with a hammermill and packed into plastic bags. For the transport to Holland each plastic bag was packed in its turn into two jute sacks.

\section{The fodder samples}

The experimental fodder was partly harvested in the year 1959 and partly in the year 1960.

\section{SAMPLES OF 1959}

1. Kudzu (Pueraria phaseoloides). In the last months of 1955 an area of 5 hectares on clay soil was planted with $k u d z u$. In early 1959 the fodder could be regarded as full-grown and so it was cut on 27th-28th January and dried in 17 hours at temperatures between $70-80^{\circ} \mathrm{C}$.

2. Elephant grass (Pennisetum purpureum). This grass was planted in 1953 on loamy soil and since then regularly harvested. After the cutting on 28th April the grass was fertilized with $20 \mathrm{~kg} \mathrm{~N}, 40 \mathrm{~kg} \mathrm{P}_{2} \mathrm{O}_{5}$ and $50 \mathrm{~kg} \mathrm{~K} \mathrm{~K}_{2} \mathrm{O}$ per ha. After 6 weeks the fodder was full-grown and so it was cut on 9th June. The dry-matter content amounted to $11,2 \%$ (wet season). It was dried in $171 / 2$ hours at temperatures between $75^{\circ}$ and $80{ }^{\circ} \mathrm{C}$.

3. Lucuntu grass (Ischaemum timorense). This grass sample came from a pasture on clay soil. After grazing, the pasture was fertilized on 27th June with $20 \mathrm{~kg} \mathrm{~N}$, $40 \mathrm{~kg} \mathrm{P}_{2} \mathrm{O}_{5}$ and $50 \mathrm{~kg} \mathrm{~K} \mathrm{~K}_{2} \mathrm{O}$ per ha. The growth of the grass was excellent. On 29 th July the grass was cut with $16,7 \%$ of dry matter. It was dried in $201 / 4$ hours at a temperature of $75-80{ }^{\circ} \mathrm{C}$.

4. Para grass (Brachiaria purpurascens). This grass growing on clay soil, was cut for the last time on 24th June. After fertilizing on 3rd-4th July with $20 \mathrm{~kg} \mathrm{~N}$, $40 \mathrm{~kg} \mathrm{P}_{2} \mathrm{O}_{5}$ and $50 \mathrm{~kg} \mathrm{~K}_{2} \mathrm{O}$ per ha the grass grew luxuriantly. It was cut on 4th August with $21,0 \%$ of dry matter. It was dried in $20^{1 / 2}$ hours at $75-77{ }^{\circ} \mathrm{C}$.

SAMPLES OF 1960

1. Coastal Bermuda grass (Cynodon dactylon). This grass was planted in November 1959 on sandy soil. After a last cutting on 20th June the grass was fertilized with $30 \mathrm{~kg} \mathrm{~N}, 40 \mathrm{~kg} \mathrm{P}_{2} \mathrm{O}_{5}$ and $50 \mathrm{~kg} \mathrm{~K} 2 \mathrm{O}$ per ha. After 29 days, on 19 th July, the grass was cut. It was dried in 29 hours at a temperature of $70{ }^{\circ} \mathrm{C}$.

2. Guatemala grass (Tripsacum laxum). This grass was planted in November 1959 on sandy soil. The fodder was cut on 28th June. After cutting it was fertilized with $30 \mathrm{~kg} \mathrm{~N}, 40 \mathrm{~kg} \mathrm{P}_{2} \mathrm{O}_{5}$ and $50 \mathrm{~kg} \mathrm{~K} 2 \mathrm{O}$ per ha. On 9th August the grass was harvested. It was dried in $221^{1 / 2}$ hours at a temperature of $65^{\circ} \mathrm{C}$.

3. Kudzu (Pueraria phaseoloides). The plantation was more than 5 years old and situated on sandy soil. Because the plantation showed clear deficiency symptoms it was fertilized on 27th May with $100 \mathrm{~kg} \mathrm{P}_{2} \mathrm{O}_{5}$ and $100 \mathrm{~kg} \mathrm{~K} 2 \mathrm{O}$ per ha. Then, during the wet season there was an excellent growth. On 16th August the fodder was harvested. It was dried during 26 hours at $65-70^{\circ} \mathrm{C}$.

\section{The digestion trials}

As mentioned already, about $100 \mathrm{~kg}$ of each lot of artificially dried fodder has been transported to our Institute at Hoorn for digestibility determinations. 
In each digestion trial three wethers were used. The daily rations were chosen so that they were still eaten by the animals without refusals. To the experimental fodder no other feeding stuffs were added than only $5 \mathrm{~g}$ common salt per animal per day. Each digestion trial consisted of an experimental period of 10 days, preceded by a preliminary period of 10 days. The results of these experiments are mentioned in TABLE 1 and 2.

Table 1. Composition of the dry matter and digestion coefficients of the fodder in 1959

\begin{tabular}{|c|c|c|c|c|c|c|c|c|}
\hline & $\begin{array}{l}\text { Consumed } \\
\text { quantity } \\
\text { (g) }\end{array}$ & $\underset{\text { matter }}{\text { Dry }}$ & $\begin{array}{c}\text { Organic } \\
\text { matter }\end{array}$ & $\begin{array}{l}\text { Crude } \\
\text { pro- } \\
\text { tein }\end{array}$ & $\begin{array}{l}\text { N-free } \\
\text { extract } \\
+ \text { fat }\end{array}$ & $\begin{array}{l}\text { Crude } \\
\text { fibre }\end{array}$ & Ash & $\begin{array}{l}\text { True } \\
\text { pro- } \\
\text { tein }\end{array}$ \\
\hline $\begin{array}{l}\text { Kudzu (V 566) } \\
\text { Composition (\%) } \ldots \ldots \ldots \ldots \\
\text { Digestion coefficients: }\end{array}$ & & 88,35 & & 12,76 & 41,03 & 39,41 & 6,80 & 10,88 \\
\hline 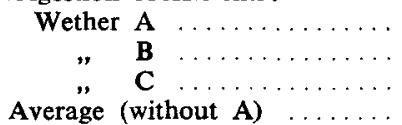 & $\begin{array}{l}800 \\
800 \\
800 \\
800\end{array}$ & $\begin{array}{l}54,3 \\
42,6 \\
44,2 \\
43,4\end{array}$ & $\begin{array}{l}55,5 \\
44,0 \\
45,5 \\
44,8\end{array}$ & $\begin{array}{l}60,6 \\
59,6 \\
50,3 \\
55,0\end{array}$ & $\begin{array}{l}64,5 \\
56,0 \\
58,9 \\
57,4\end{array}$ & $\begin{array}{l}44,4 \\
26,3 \\
30,0 \\
28,2\end{array}$ & $\begin{array}{l}39,1 \\
23,7 \\
25,8 \\
24,8\end{array}$ & $\begin{array}{l}54,6 \\
53,7 \\
45,0 \\
49,4\end{array}$ \\
\hline $\begin{array}{l}\text { Elephant grass (V 586) } \\
\text { Composition }(\%) \quad \ldots \ldots \ldots \ldots \\
\text { Digestion coefficients: }\end{array}$ & & 83,23 & & 12,28 & 40,28 & 34,88 & 12,56 & 9,62 \\
\hline 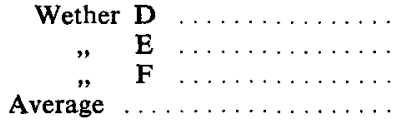 & $\begin{array}{l}1000 \\
1000 \\
1000 \\
1000\end{array}$ & $\begin{array}{l}59,4 \\
61,1 \\
58,5 \\
59,7\end{array}$ & $\begin{array}{l}62,5 \\
64,4 \\
61,5 \\
62,8\end{array}$ & $\begin{array}{l}64,1 \\
63,8 \\
63,9 \\
63,9\end{array}$ & $\begin{array}{l}61,3 \\
63,6 \\
59,8 \\
61,6\end{array}$ & $\begin{array}{l}63,4 \\
65,6 \\
62,7 \\
63,9\end{array}$ & $\begin{array}{l}38,1 \\
37,6 \\
37,2 \\
37,6\end{array}$ & $\begin{array}{l}57,7 \\
56,8 \\
57,6 \\
57,4\end{array}$ \\
\hline $\begin{array}{l}\text { Lucuntu grass (V 591) } \\
\text { Composition }(\%) \quad \ldots \ldots \ldots \ldots \\
\text { Digestion coefficients : }\end{array}$ & & 90,86 & & 8,34 & 46,90 & 34,16 & 10,60 & 6,75 \\
\hline 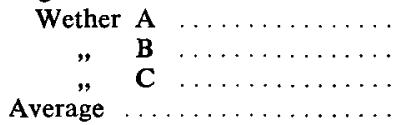 & $\begin{array}{l}1000 \\
1000 \\
1000 \\
1000\end{array}$ & $\begin{array}{l}51,7 \\
51,9 \\
50,5 \\
51,4\end{array}$ & $\begin{array}{l}54,5 \\
54,6 \\
53,4 \\
54,2\end{array}$ & $\begin{array}{l}44,6 \\
46,2 \\
42,0 \\
44,3\end{array}$ & $\begin{array}{l}51,7 \\
51,5 \\
49,8 \\
51,0\end{array}$ & $\begin{array}{l}60,9 \\
60,9 \\
61,1 \\
61,0\end{array}$ & $\begin{array}{l}27,7 \\
29,1 \\
25,5 \\
27,4\end{array}$ & $\begin{array}{l}33,9 \\
33,8 \\
29,2 \\
32,3\end{array}$ \\
\hline $\begin{array}{l}\text { Para grass (V 592) } \\
\text { Composition }(\%) \quad \ldots \ldots \ldots \ldots \\
\text { Digestion coefficients : }\end{array}$ & & 91,96 & & 8,23 & 46,47 & 36,81 & 8,49 & 6,45 \\
\hline 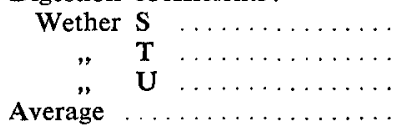 & $\begin{array}{r}800 \\
1000 \\
1000 \\
933\end{array}$ & $\begin{array}{l}52,3 \\
52,7 \\
55,1 \\
53,4\end{array}$ & $\begin{array}{l}53,2 \\
53,5 \\
56,1 \\
54,3\end{array}$ & $\begin{array}{l}53,4 \\
54,4 \\
55,4 \\
54,4\end{array}$ & $\begin{array}{l}55,9 \\
55,5 \\
57,5 \\
56,3\end{array}$ & $\begin{array}{l}49,8 \\
50,8 \\
54,4 \\
51,7\end{array}$ & $\begin{array}{l}42,7 \\
44,2 \\
44,9 \\
43,9\end{array}$ & $\begin{array}{l}42,7 \\
43,7 \\
45,4 \\
43,9\end{array}$ \\
\hline
\end{tabular}

The experiments passed off without troubles. Only in the first experiment with kudzu (V 566) wether A got a serious constipation by which the experimental period of this animal had to be finished after 7 days. In consequence of this constipation the digestion coefficients of this wether were much higher than those of both other animals. Consequently, these coefficients of wether $A$ are left out in the final average. In the experiment with Guatemala grass (V 623) the digestion coefficients of wether $Q$ differed so much that these coefficients are excluded in the calculation of the average values.

In comparison with Dutch figures the digestion coefficients of this artificially dried roughage were very low. The lowest digestion coefficients of organic matter were found in the two samples $k u d z u$; this is due to the very low digestion coefficients of crude fibre. Consequently, the feeding value of this cut $k u d z u$ was rather disap- 
TABLE 2. Composition of the dry matter and digestion coefficients of the fodder in 1960

\begin{tabular}{|c|c|c|c|c|c|c|c|c|}
\hline & $\begin{array}{l}\text { Consumed } \\
\text { quantity } \\
\text { (g) }\end{array}$ & $\underset{\text { matter }}{\text { Dry }}$ & $\begin{array}{c}\text { Organic } \\
\text { matter }\end{array}$ & $\begin{array}{l}\text { Crude } \\
\text { pro- } \\
\text { tein }\end{array}$ & $\begin{array}{l}\text { N-free } \\
\text { extract } \\
+ \text { fat }\end{array}$ & $\begin{array}{l}\text { Crude } \\
\text { fibre }\end{array}$ & Ash & $\begin{array}{l}\text { True } \\
\text { pro- } \\
\text { tein }\end{array}$ \\
\hline $\begin{array}{l}\text { Coastal Bermuda grass (V } 622) \\
\text { Composition }(\%) \ldots \ldots \ldots \ldots \\
\text { Digestion coefficients : }\end{array}$ & & 91,87 & & 9,68 & 46,14 & 35,50 & 8,68 & 7,59 \\
\hline 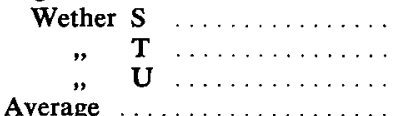 & $\begin{array}{l}900 \\
900 \\
900 \\
900\end{array}$ & $\begin{array}{l}43,2 \\
45,5 \\
45,0 \\
44,6\end{array}$ & $\begin{array}{l}48,6 \\
51,9 \\
50,5 \\
50,3\end{array}$ & $\begin{array}{l}51,2 \\
53,1 \\
50,5 \\
51,6\end{array}$ & $\begin{array}{l}47,6 \\
51,6 \\
51,7 \\
50,3\end{array}$ & $\begin{array}{l}49,2 \\
52,1 \\
49,0 \\
50,1\end{array}$ & $\begin{array}{l}-13,4 \\
-22,4 \\
-12,4 \\
-16,1\end{array}$ & $\begin{array}{l}40,1 \\
43,2 \\
43,5 \\
42,3\end{array}$ \\
\hline $\begin{array}{l}\text { Guatemala grass (V 623) } \\
\text { Composition (\%) } \ldots \ldots \ldots \ldots \\
\text { Digestion coefficients : }\end{array}$ & & 88,72 & & 9,34 & 47,85 & 37,50 & 5,31 & 7,42 \\
\hline $\begin{array}{ccc}\text { Wether } & \mathbf{P} & \ldots \ldots \\
" & \mathbf{Q} & \ldots \ldots\end{array}$ & $\begin{array}{l}900 \\
900 \\
900 \\
900\end{array}$ & $\begin{array}{l}57,2 \\
48,6 \\
55,2 \\
56,2\end{array}$ & $\begin{array}{l}58,8 \\
50,4 \\
56,5 \\
57,6\end{array}$ & $\begin{array}{l}54,8 \\
50,5 \\
53,6 \\
54,2\end{array}$ & $\begin{array}{l}58,6 \\
50,3 \\
56,1 \\
57,4\end{array}$ & $\begin{array}{l}60,1 \\
50,4 \\
57,6 \\
58,8\end{array}$ & $\begin{array}{l}29,0 \\
17,5 \\
33,0 \\
31,0\end{array}$ & $\begin{array}{l}44,3 \\
40,5 \\
43,1 \\
43,7\end{array}$ \\
\hline $\begin{array}{l}\text { Kudzu (V 621) } \\
\text { Composition (\%) } \ldots \ldots \ldots \ldots \\
\text { Digestion coefficients: }\end{array}$ & & 89,44 & & 18,03 & 34,67 & 41,26 & 6,04 & 13,56 \\
\hline 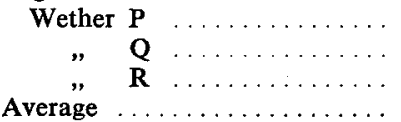 & $\begin{array}{l}900 \\
900 \\
900 \\
900\end{array}$ & $\begin{array}{l}48,7 \\
48,3 \\
49,2 \\
48,7\end{array}$ & $\begin{array}{l}49,9 \\
49,2 \\
50,0 \\
49,7\end{array}$ & $\begin{array}{l}67,1 \\
67,2 \\
67,4 \\
67,2\end{array}$ & $\begin{array}{l}58,1 \\
57,1 \\
59,4 \\
58,2\end{array}$ & $\begin{array}{l}35,5 \\
34,6 \\
34,5 \\
34,9\end{array}$ & $\begin{array}{l}29,0 \\
34,0 \\
36,2 \\
33,1\end{array}$ & $\begin{array}{l}58,3 \\
58,6 \\
58,4 \\
58,4\end{array}$ \\
\hline
\end{tabular}

pointing. However, the feeding value of $k u d z u$ will probably be much higher under grazing conditions, as the animals will mainly consume the leaves and young shoots. The digestibility of organic matter of the grasses varied between 50,3 and $57,6 \%$, only that of elephant grass was distinctly higher $(62,8 \%)$. Generally, the digestion coefficient of crude protein depends on the protein percentage. Consequently, the highest figure was found in the second sample of $k u d z u$. The lowest coefficient for crude protein was found in the sample lucuntu grass $(44,3 \%)$.

\section{The feeding value}

At Hoorn the fat content of roughage is not determined. Consequently, the sum of crude fat and $\mathrm{N}$-free extract are given in a single figure. This is done because the "crude fat" obtained in an ordinary fat determination (by extraction with ether) consists only partly of genuine fat. It consists of vegetable components, plant pigments such as xanthophyll, chlorophyll, etc. which likewise dissolve in ether. The omission of the determination of the fat content gives a considerable simplification in the total analysis. By our simplified method for the calculation of the starch equivalent, the determination of true protein can also be left out.

Consequently, in samples of roughage, only the contents of the following components have to be determined: moisture, ash, crude protein and crude fibre. By adding up the percentages of these components, and subtracting the total from 100 , the percentage of $\mathrm{N}$-free extract + fat is obtained.

If the content of minerals and vitamins - which, as is known, are also of extremely great importance - is left out of consideration, the feeding value of a roughage 
will be mainly determined by its content of digestible crude protein and by its starch equivalent.

The conception of starch equivalent was introduced by KeLLNER, who expressed the value of a feeding stuff in terms of its fat-forming capacity in comparison with starch. According to him the starch equivalent of a roughage is: Starch equivalent $=0,94 \mathrm{dig}$. true protein $+1,91 \mathrm{dig}$. fat $+1,00 \mathrm{dig}$. $\mathrm{N}$-free extract $+1,00 \mathrm{dig}$. crude fibre - factor $\times$ crude fibre.

This crude-fibre deduction factor depends on the crude-fibre content of the roughage. In the case of hay this factor is 0,58 and in the case of fresh forage crops with less thans $4 \%$ crude fibre, it is 0,29 . This factor gradually increases from 0,29 in the case of $4 \%$ crude fibre to 0,58 in roughages with $16 \%$ or more crude fibre.

At Hoorn a simplified method of calculating starch equivalent is always applied for roughages. As has been mentioned, the fat content is not determined separately but is combined with the $\mathrm{N}$-free extract in one figure.

Accordingly, digestible fat is multiplied by 1,00 instead of by 1,91 , and owing to this, the starch equivalent will be rather too low. This, however, is corrected at Hoorn by carrying out calculations with dig. crude protein instead of with dig. true protein - which causes the starch equivalent to be somewhat higher, so that the final result is almost the same. Thus, by applying this simplified method, not only determination of fat but also determination of true protein can be dispensed with.

By the above mentioned method, we therefore obtain: Starch equivalent $=0,94 \mathrm{dig}$. crude protein $+1,00$ dig. $N$-free extract (fat included) $+1,00 \mathrm{dig}$. crude fibre factor $\times$ crude fibre.

From the figures of the TABLES 1 and 2 we have calculated the digestible crudeprotein content and the starch equivalent of each of the samples. However, there was still one difficulty in the calculation of the starch equivalent. We don't know the dry-matter content of each of the samples at the moment of cutting. Consequently, we were not able to calculate the crude-fibre content in the fresh material and so we could not chose the right crude-fibre deduction factor.

Also in view of a good comparison we have assumed that in all samples the drymatter content of the fresh material was $20 \%$. In that case the crude-fibre deduction factor varies from 0,36 to 0,39 . The feeding value figures calculated in this way, are mentioned in TABLE 3.

TABLE 3. Feeding value of the dry matter of the fodder used in the digestion trials

\begin{tabular}{|c|c|c|}
\hline & $\begin{array}{c}\text { Digestible } \\
\text { crude protein }\end{array}$ & $\begin{array}{c}\text { Starch } \\
\text { equivalent }\end{array}$ \\
\hline \multicolumn{3}{|l|}{ Experiments in 1959} \\
\hline 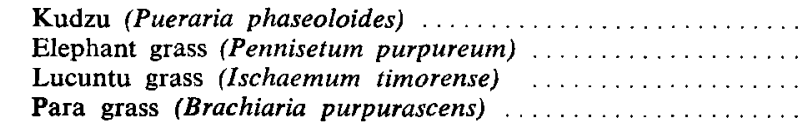 & $\begin{array}{l}7,02 \\
7,85 \\
3,69 \\
4,48\end{array}$ & $\begin{array}{l}26,3 \\
41,9 \\
35.9 \\
35,8\end{array}$ \\
\hline \multicolumn{3}{|l|}{ Experiments in 1960} \\
\hline $\begin{array}{l}\text { Coastal Bermuda grass (Cynodon dactylon) } \ldots \ldots \ldots \ldots \ldots \ldots \\
\text { Guatemala grass (Tripsacum laxum) } \ldots \ldots \ldots \ldots \ldots \ldots \ldots \ldots \ldots \ldots \ldots \ldots \ldots \\
\text { Kudzu (Pueraria phaseoloides) } \ldots \ldots \ldots \ldots \ldots \ldots \ldots \ldots\end{array}$ & $\begin{array}{r}4,99 \\
5,06 \\
12,12\end{array}$ & $\begin{array}{l}32,9 \\
40,4 \\
29,9\end{array}$ \\
\hline
\end{tabular}

The digestible crude-protein content of the grasses varied in the dry matter from 3,7 to $7,8 \%$. The dig. crude-protein content of the $k u d z u$ was in the first experiment $7,0 \%$ and in the second experiment $12,1 \%$. 
The starch equivalent of the grasses varied in the dry matter from 33 to 42 and in both samples of cut $k u d z u$ from 26 to 30 . Especially the starch equivalent of $k u d z u$ remained far behind the expectations. The feeding value of the fresh grasses in Surinam can be compared with that of Dutch hay.

\section{Relation between chemical composition and feeding value}

Years ago, when we made a study of the feeding value of Dutch hay- (Brouwer and DijKstra, 1938) and grass samples (DiJKstra and Brouwer, 1939) we were aware of the practical impossibility to carry out a digestion trial on every roughage sample. And nevertheless we found it of great importance that farmers should be as well informed as possible regarding the feeding value of the roughages for their animals. The only practical possibility is to determine the chemical composition of the roughage samples submitted. Accordingly, we have made endeavours to estimate the feeding value of hay- and grass samples as well as possible from the results of these chemical analyses.

We have therefore tried to determine whether, perhaps, a relationship existed between composition and feeding value. For if this should be the case, it might be possible to define the relationship in a formula and by means of that the feeding value of a roughage sample of which the composition is known, might be calculated.

As has already been mentioned, the following components were determined in analysis: moisture, ash, crude protein, crude fibre and indirectly $\mathrm{N}$-free extract + fat. Since moisture and ash do not produce energy, it was possible to achieve a further degree of simplification by provisionally converting everything into terms of organic matter. Accordingly, the only remaining figures are those for crude protein, crude fibre and $\mathrm{N}$-free extract + fat; only the first two of these need be used in making calculations, because on organic matter basis $\mathrm{N}$-free extract + fat $=100$ - crude protein - crude fibre.

For the feeding value it was obvious for us to choose digestible crude protein and starch equivalent.

In our first experiments we found that there was as well in hay as in grass a close correlation between crude protein and digestible crude protein and a rather good correlation between crude fibre and starch equivalent. These relationships were expressed in regression formulae. These first formulae are on organic-matter basis, but by a very simple calculation it is possible to convert them to formulae in the dry matter.

We have calculated such regression formulae not only for Dutch hay and grass, but lateron also for artificially dried grass, grass-silage and many other roughages. All these regression equations are transposed into tables which are laid down in "Manual for the calculation of the nutritive value of roughages" (Anon., 1958).

Till so far we had only made a study of roughages grown in the Netherlands. Now we got the opportunity to determine the feeding value of some tropical roughages and we were keen to examine how far it would be possible to come to a reliable estimation of the feeding value of tropical grasses too.

Because the number of samples from our own experiments was too small, we have also drawn into our study the results of a number of foreign digestion trials with some of the most important tropical grasses. The converted data of the experiments in the literature which were at our disposal are mentioned in TABLE 4. 
DIGESTIBILITY AND FEEDING VALUE OF SOME TROPICAL GRASSES AND KUDZU

TABLE 4. Figures converted to percentages of the organic matter

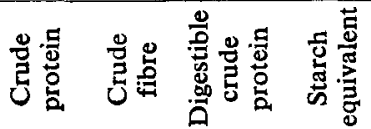

Elephant grass (Pennisetum purpureum)

\begin{tabular}{|c|c|c|c|c|}
\hline ranganyika ... & 11,42 & 34,55 & 6,58 & 57,0 \\
\hline & 10,54 & 33,54 & 5,37 & 47,0 \\
\hline & 8,18 & 41,15 & 3,75 & 39 , \\
\hline Trinidad & 8,88 & 34,41 & 5,68 & 51 , \\
\hline & 12,11 & 32,71 & 7,88 & 47, \\
\hline & 8,70 & 40,36 & 5,24 & 54,7 \\
\hline Puerto Rico & 5,46 & 39,24 & 3,50 & 46 \\
\hline & 6,09 & 41,67 & 3,84 & 50 , \\
\hline & 4,83 & 38,45 & 2,32 & 39 \\
\hline & 8,37 & 36,70 & 5,19 & 47, \\
\hline & 12,75 & 36,00 & 8,29 & \\
\hline & 11,02 & 36,59 & 7,16 & \\
\hline Hawaii & 5,11 & & 3,07 & \\
\hline & 5,94 & & 3,15 & \\
\hline Ind & 5,25 & 38,80 & 3,28 & \\
\hline
\end{tabular}

Guatemala grass (Tripsacum laxum)

$\begin{array}{rrrrrr}\text { Puerto Rico . } & 5,40 & 40,01 & 3,24 & 57,8 \\ & & 4,69 & 36,32 & 2,53 & 51,2 \\ & & 5,68 & 38,92 & 3,19 & 53,7 \\ \text { Trinidad ...... } & 5,04 & 34,06 & 2,92 & 57,2 \\ & & 10,06 & 43,04 & 6,30 & 48,6 \\ & & 9,22 & 36,81 & 7,14 & 44,7 \\ & & 37,87 & 4,37 & 42,0\end{array}$

Guinea grass (Panicum maximum)

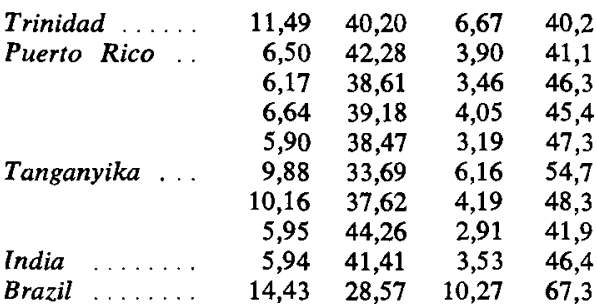

Rhodes grass (Chloris gayana)

$\begin{array}{lrlll}\text { South Africa . . } & 7,31 & 43,33 & 2,59 & 46,3 \\ \text { East Africa . . } & 14,13 & 33,57 & 9,30 & 53,1 \\ & 9,38 & 38,34 & 5,24 & 43,9 \\ & 9,27 & 42,86 & 5,38 & 51,1\end{array}$

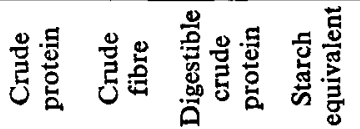

Para grass (Brachiaria mutica)

\begin{tabular}{|c|c|c|c|c|}
\hline \multirow[t]{2}{*}{ Trinidad } & 10,94 & 39,44 & 7,33 & 46,5 \\
\hline & 8,33 & 34,20 & 5,56 & 47,5 \\
\hline \multirow[t]{4}{*}{ Puerto Rico } & 7,30 & 34,09 & 4,82 & 53,9 \\
\hline & 3,30 & 35,05 & 1,39 & 54,6 \\
\hline & 4,23 & 35,43 & 1,65 & 42,1 \\
\hline & 2,96 & 35,03 & 0,51 & 42,0 \\
\hline Hawa & 9,22 & 39,15 & 5,54 & 52,9 \\
\hline
\end{tabular}

Bermuda grass (Cynodon dactylon)

\begin{tabular}{|c|c|c|c|c|}
\hline \multirow[t]{2}{*}{ India } & 12,69 & & 6,91 & \\
\hline & 5,70 & 33,12 & 1,95 & 50,4 \\
\hline \multirow[t]{5}{*}{ Georgia } & 23,42 & 25,23 & 18,59 & 63,0 \\
\hline & 19,85 & 28,13 & 15,48 & 59,9 \\
\hline & 18,11 & 28,09 & 13,83 & 58,4 \\
\hline & 13,02 & 28,41 & 9,25 & 58,7 \\
\hline & 11,08 & 30,10 & 7,03 & 51,2 \\
\hline Brazil & 6,86 & 26,30 & 3,99 & 62,6 \\
\hline \multirow{3}{*}{ Tanganyika } & 22,00 & 26,04 & 16,65 & 58,8 \\
\hline & 12,37 & 34,15 & 8,69 & 49,3 \\
\hline & 12,42 & 34,17 & 8,66 & 45,4 \\
\hline
\end{tabular}

Mixture of several grasses

$\begin{array}{rrrrrr}\text { South } \text { Africa ...... } & 6,15 & 43,16 & 2,54 & 36,6 \\ & & 7,74 & 41,86 & 3,98 & 42,7 \\ 9,98 & 39,50 & 6,03 & 46,7 \\ 11,71 & 38,10 & 7,44 & 52,8 \\ 4,97 & 41,52 & 1,62 & 36,5 \\ 5,61 & 41,26 & 2,22 & 40,3 \\ & & & \\ & & 38,13 & 38 & 3,60 & 46,9 \\ & 8,10 & 38,37 & 4,47 & 50,8 \\ & 9,50 & 38,68 & 5,73 & 54,2\end{array}$

Our own experiments

$\begin{array}{llrrrr}\text { Elephant grass . . . . } & 14,04 & 39,89 & 8,97 & 50,7 \\ \text { Lucuntu grass . . . . } & 9,33 & 38,21 & 4,13 & 42,9 \\ \text { Para grass . . . . . . . } & 8,99 & 40,23 & 4,89 & 42,3 \\ \text { Coastal Bermuda } & \text { grass } & 10,60 & 38,87 & 5,47 & 38,8 \\ \text { Guatemala grass . . . . } & 9,86 & 39,60 & 5,34 & 45,8 \\ \text { Kudzu . . . . . . . . . } & 13,69 & 42,29 & 7,53 & 32,0 \\ \text { Kudzu . . . . . . . . . } & 19,19 & 43,91 & 12,90 & 36,2\end{array}$

At first the starch equivalent of each of these samples is calculated. For an exact comparison we have in all cases used the same crude-fibre deduction factor and in imitation of Dutch grasses the factor 0,29 is chosen. Further all analyses and feedingvalue figures are converted to organic-matter basis. In this table three very aberrant crude-fibre contents and starch equivalents are omitted. 


\subsection{Digestible crude protein}

To be able to overlook the relation between the crude-protein content and the digestible crude-protein content in these tropical grasses, we have plotted in FIG. 1 on the horizontal axis the crude-protein content of these samples and on the vertical axis the digestible crude-protein content.

FIG. 1. Relation between crude protein and digestible crude protein in the samples of tropical grasses

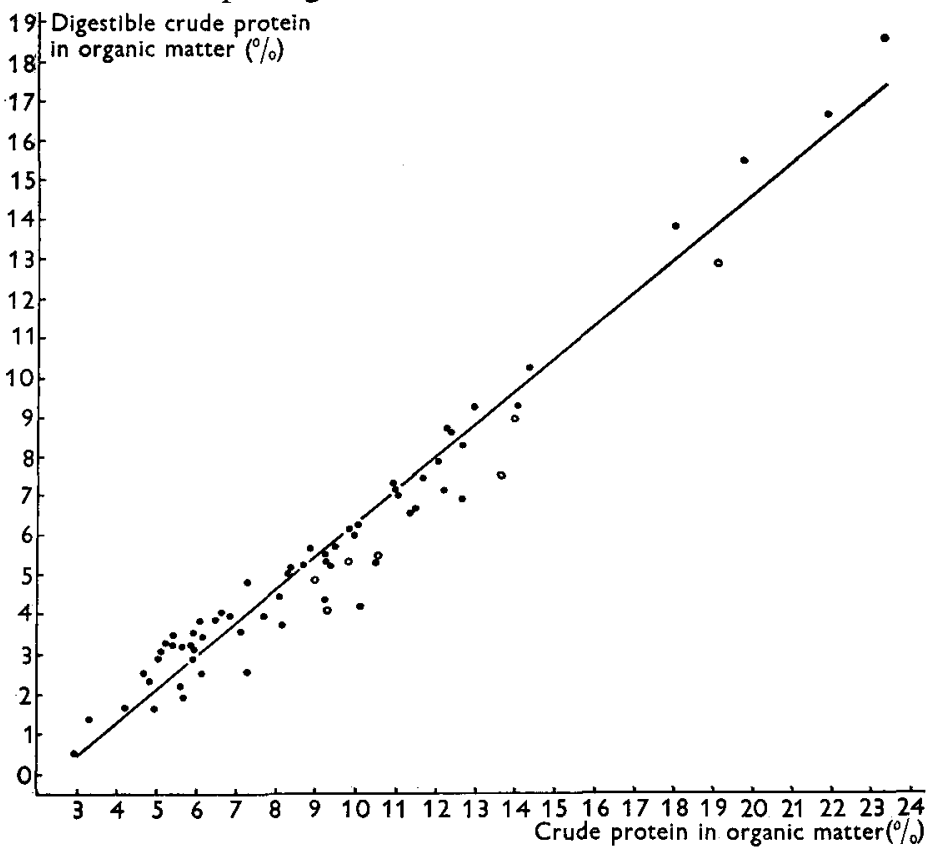

- Samples from literature

- Samples from own experiments

The figure demonstrates already that there is a good relation between both factors. The correlation coefficient of the 63 samples from the literature amounted to 0,980 ; consequently a very close correlation. The regression line drawn in the figure is calculated of the data from the literature only. Our own figures lay all below the line.

This is obvious, for the artificially drying will undoubtedly have diminished the digestibility of the protein (DIJKSTrA, 1954). True, the drying temperatures were not very high but also the drying-time plays a certain part and this was at least 17 hours.

The formula of the calculated regression line is :

$$
d=0,827 x-1,987
$$

in which : $d=$ digestible crude-protein content and $x=$ crude-protein content, both converted into organic matter.

For the practical use this equation has to be converted into dry matter. We will demonstrate in which way this can be done. 
We mention: $d^{\prime}=$ dig. crude protein $(\%)$ in dry matter

$$
\begin{aligned}
& x^{\prime}=\text { crude protein }(\%) \text { in dry matter } \\
& m^{\prime}=\text { ash }(\%) \text { in dry matter }
\end{aligned}
$$

We know that:

$$
x=\frac{100 x^{\prime}}{100-m^{\prime}} \text { and } d=\frac{100 d^{\prime}}{100-m^{\prime}}
$$

When we add these data in the regression equation and we multiply each of the factors with $\frac{100-m^{\prime}}{100}$, then we will obtain the following equation :

$$
d^{\prime}=0,827 x^{\prime}-1,987 \frac{100-m^{\prime}}{100} \text { or } d^{\prime}=0,827 x^{\prime}+0,020 m^{\prime}-1,987
$$

or written in a more common way:

$$
d^{\prime}=0,827\left(x^{\prime}-9\right)+0,020\left(m^{\prime}-10\right)+5,656
$$

The digestible crude-protein content in the dry matter depends mainly on the crudeprotein content with only a very small correction for the ash content.

\subsection{Starch equivalent}

In many Dutch roughages a rather good correlation consists between crude-fibre content and starch equivalent. However, the circumstances for growth in the tropics are quite different of those in the temperate zones. The herbage growth in the tropics is largely conditioned by rainfall. The variation in the quantity and distribution of rain stimulates periods of rapid growth which are separated by dessiccating intervals when growth ceases and the herbage dries up. But also the high temperatures are responsible for the luxurious growth, eventually a quick lignification.

By this the chance of a good correlation between crude-fibre content and starch equivalent will be smaller in tropical grasses than in Dutch grass.

In FIG. 2 we have plotted on the horizontal axis the crude-fibre content of the tropical grasses mentioned in TABLE 4 and on the vertical axis the starch equivalents. Also our own data are plotted in this figure.

The figure shows that there is still a certain relation between both factors. The correlation coefficient of all samples amounted to $-0,692$. This coefficient justifies in our opinion the calculation of a regression line.

The formula of the line drawn in FIG. 2 is :

$$
S=-1,067 y+88,10
$$

in which : $S=$ starch equivalent and $y=$ crude-fibre content, both converted into organic matter.

For the practical use this formula is converted into dry matter :

$$
S^{\prime}=-1,067\left(y^{\prime}-33\right)-0,881\left(m^{\prime}-10\right)+44,07
$$

The starch equivalent in the dry matter depends as well on the crude-fibre content as on the ash content.

In most cases the starch equivalent calculated in this way will be too high, for in this calculation a crude-fibre deduction factor of 0,29 is used. Especially in tropical roughage this factor will be higher and so the starch equivalent must be corrected on this higher crude-fibre content.

The starch equivalents of 5 of our 7 samples lay below the calculated value. Especially the starch equivalent of $k u d z u$ is much lower. Perhaps this is due to the lignification of this legume. 
Fig. 2. Relation between crude-fibre content and starch equivalent in the samples of tropical grasses

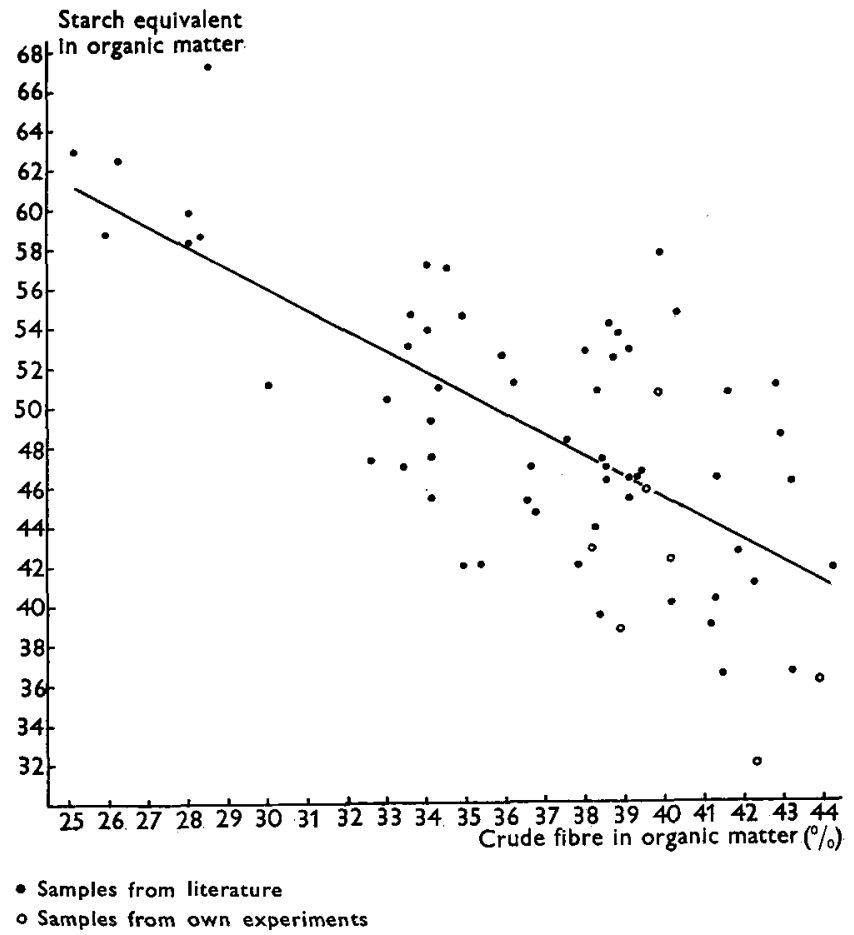

\section{T ERA T URE}

Anon.

1958 Manual for the calculation of the nutritive value of roughages. Oosterbeek, Netherlands, 1958.

AXTMAYer, J. H.,

C. F. AsENJo and

D. H. COOK

AXTMAYER, J. H., G. RIVERA-HERNANDEZ and D. H. Cook

BrouWER, E., and N. D. DiJKstra

DiJKstra, N. D., and E. BrouWER

DiJKsTRA, N. D. FRENCH, M. H.

1938 Puerto Rico Univ. Journ. Agr. 22, 95.

1938 Puerto Rico Univ. Journ. Agr. 22, 455.

1938 Versl. landbk. Onderz. No. 44, 529.

1939 Versl. landbk. Onderz. No. 45, 1.

1954 Neth. J. agric. Sci. 2, 273.

1941 Empire Journ. Expt. Agr. 9, 23.

1943 East Afr. Agr. Journ. 8, 126.

1957 Herbage Abstracts. 27, 1.

Harrison, E.

1942 Trop. Agr., Trinidad. 19, 147.

KIDDER, R. W.

1945 Journ. Agr. Res. 70, 89.

KNOX, F. E., G. W. BuR-

1958 Journ. Agr. Food Chem. 6, 217. TON and D. M. BAIRD 
DIGESTIBILITY AND FEEDING VALUE OF SOME TROPICAL GRASSES AND KUDZU

LANDER, P. E., and P. L. C. Dharmani

Louw, J. G.

MILFORD, $R$.

NORDFELDT, S., I. IWANAGA, A. K. S. TOM and L. A. Henke

Pulle, A.

Rocha, LEME DA, G. M. BECKER, F. BORGES

BATELHO and H. DA SilveIRA CORRÊA

TODD, J. R.

WORK, S. H.

WIJK, H. P. D. VAN,

S. A. Oosthuizen and

E. E. MEYER
1932 Ind. Journ. Vet. Sci. and Anim. Husb. 2, 141.

1936 Ind. Journ. Vet. Sci. and Anim. Husb. 6, 117.

1938 Onderstepoort Journ. Vet. Sci. and Anim. Indust. 11, 163.

1960 Austr. Journ. Agr. Res. 11, 138.

1951 Univ. Hawaii Agr. Exp. Sta. Techn. Bull. No. 12, 8.

Flora of Surinam.

1951 Bol. Indust. Anim. 12, 119.

1956 Journ. Agr. Sci. 47, 35.

1937 Hawaii Agr. Exp. Sta. Ann. Rpt. 1937, 77.

1946 Univ. Hawaii Agr. Exp. Sta. Techn. Bull. No. 4.

Dep. Agr. S. Afr. Sci. Bull. No. 354. 